\title{
PENGARUH LATIHAN KNEE TUCK JUMP TERHADAP KEMAMPUAN SMASH DALAM PERMAINAN BOLA VOLI PADA UKM IKIP MATARAM
}

\author{
Lalu Sapta Wijaya Kusuma \\ Dosen Pendidikan Olahraga IKIP Mataram
}

\begin{abstract}
Abstrak; Pengaruh Latihan Knee Tuck Jump Terhadap Kemampuan Smash Dalam Permainan Bola Voli, dengan rumusan permasalah adalah apakah ada pengaruh latihan knee tuck jump terhadap kemampuan smash dalam permainan bola voli pada club IKIP Mataram? Sedangkan tujuan yang ingin dicapai dalam penelitian ini adalah ingin mengetahui apakah ada atau tidak Pengaruh Latihan Knee Tuck Jump Terhadap Kemampuan Smash Dalam Permainan Bola Voli club IKIP Mataram. Metode pendekatan penelitian ini adalah eksperimen dengan menggunakan bentuk rancangan one group pre-test post-test disign. Sampel dalam penelitian ini adalah 30 siswa yang tergabung dalam ekstrakurikuler bola voli. Hasil penelitian ini menunjukkan bahwa t-hitung yang diperoleh lebih besar dari pada t-tabel pada taraf signifikan 5\% yaitu $7.55>2,045$, dengan derajat kebebasan N-1 (30-1= 29). Jadi hipotesis yang menyatakan $(\mathrm{Ha})$ yang berbunyi ada Pengaruh Latihan Knee Tuck Jump Terhadap Kemampuan Smash Dalam Permainan Bola Voli club IKIP Mataram, diterima. sedangkan hipotesis (Ho) yang menyatakan tidak ada Pengaruh Latihan Knee Tuck Jump Terhadap Kemampuan Smash Dalam Permainan Bola Voli Siswa club IKIP Mataram, ditolak. Jadi dapat ditarik suatu kesimpulan dalam penelitian ini, bahwa latihan knee tuck jump mempunyai pengaruh yang signifikan terhadap peningkatan kemampuan smash club IKIP Mataram.
\end{abstract}

Kata kunci: knee tuck jump, kemampuan smash.

\section{PENDAHULUAN}

Permainan bolavoli suatu permainan yang menggunakan bola untuk dipantulkan ke udara. Di mana setiap pemain dituntut untuk dapat mempertahan bola supaya tidak menyentuh lantai atau daerahnya sendiri, akan tetapi pemain berusaha menjatuhkan bola ke daerah lawan dengan maksud untuk memperoleh poin atau angka.

Menurut

Suharno

mengungkapkan bahwa ada beberapa faktor yang mempengaruhi pencapaian prestasi maksimal dalam cabang olahraga. Faktor faktor tersebut dapat diklasifikasikan menjadi empat aspek yaitu:

a. Aspek biologis terdiri atas potensi atau kemampuan dasar tubuh, fungsi organ tubuh, postur tubuh, struktur tubuh dan gizi.

b. Aspek psikologis terdiri atas intelektual atau kecerdasan, motivasi, kepribadian, koordinasi kerja otot dan saraf.

c. Aspek lingkungan, dan

d. Aspek penunjang.

Smash adalah tindakan memukul bola ke bawah dengan kekuatan besar, biasanya meloncat ke atas, masuk ke bagian lapangan lawan. Hal itu dapat dilihat dari kerasnya bola yang dihasilkan bahwa teknik smash datangnya bola lebih keras dan lebih menyulitkan bagi penerima bola. Semua sikap memukul bola ke daerah lawan kecuali servis dan blok adalah merupakan pukulan serangan.

Salah satu unsur kondisi fisik yang harus dimiliki oleh setiap pemain pada cabang olahraga bola voli adalah power otot tungkai. Daya ledak (Power) adalah usaha yang dilakukan otot secara maksimal dalam waktu sesingkat-singkatnya yang merupakan perpaduan antara kecepatan dan kekuatan. Dalam permainan bola voli, power otot tungkai merupakan salah satu komponen kondisi fisik yang sangat penting yang berperan dalam melakukan loncatan yang tinggi.

Dalam permainan bolavoli unsur yang paling dominan adalah smash dan blocking, dimana pada unsur tersebut dibutuhkan kekuatan otot pada bagian bawah yaitu daya ledak. Salah satu metode untuk mengembangkan kemampuan daya ledak adalah dengan latihan knee tuck jump. Latihan knee tuck jump merupakan suatu bentuk latihan yang merangsang otot untuk melakukan aktivitas kerja dengan cepat. 
Rancangan penelitian adalah keseluruhan proses pemikiran dan penentuan matang tentang hal-hal yang dilakuka. Ia merupakan landasan berpijak, serta dapat dijadikan dasar penilaian baik oleh peneliti itu sendiri maupun orang lain terhadap kegiatan penelitian. Dengan demikian rancangan penelitian bertujuan untuk memberi pertanggung jawaban terhadap semua langkah yang akan diambil (Margono, 2005). Menurut Sugiyono (2010) Rancangan penelitian adalah pedomkan yang berisikan langkah-langkah yang diikuti peneliti untuk melakukan penelitiannya.

Dari pengertian diatas dapat disimpulkan rancangan penelitian adalah gambaran dari proses berpikir yang dilakukan dalam penelitian di lapangan dengan tetap mengacu pada rumusan masalah dan tujuan penelitian. Rancagan yang digunakan dalam penelitian ini adalah rancangan atau desain dengan model eksperimen. Adapun rancangan penelitian menggunakan One Group PretestPosttest Design (Maksum, 2009) dapat dilihat pada gambar 3.1 dibawah ini.

\begin{tabular}{|ccc|}
\hline $\mathbf{T}_{1}$ & $\mathrm{X}$ & $\mathbf{T}_{2}$ \\
\hline
\end{tabular}

Gambar 3.1 Rancangan Penelitian Maksum (2009).

Keterangan :

T1 : Pretest (test awal) sebelum diberikan perlakukan yaitu subjek penelitian diberikan instrument test untuk mengetahui tingkat kemampuan smash bola voli (ketepatan smash)

$\mathrm{X}$ : Perlakuan yang diberikan adalah bentuk latihan knee tuck jump untuk meningkatkan kemampuan smash dalam permainan bola voli.

T2 : Posttest (test akhir) setelah diberikan perlakuan untuk mengetahui apakah ada pengaruh latihan knee tuck jump terhadap smash dalam permaian bola voli pada subjek yang diteliti.

\section{Populasi Penelitian}

Populasi adalah seluruh penduduk yang dimaksud untuk diselidiki. Populasi dibatasi sejumlah penduduk atau individu yang paling sedikit mempunyai satu sifat sama. Menurut Maksum (2009), populasi adalah keseluruhan objek atau individu yang dimaksudkan untuk diteliti dan yang nantinya akan dikenai generalisasi. Sedangkan menurut Sunarno \& Sihombing (2011) menyatakan bahwa populasi diartikan seluruh anggota kelompok yang telah ditentukan karakteristiknya dengan jelas, baik itu kelompok orang, objek, benda atau kejadian.

Adapun yang menjadi populasi dalam penelitian ini adalah mahaiswa UKM bola voli IKIP Mataram yang berjumlah 30 orang.

\section{Instrument Penelitian}

Untuk memperoleh data yang diperlukan alat pengukuran. Yang dimaksud dengan instrumen adalah alat pada waktu penelitian dengan menggunakan suatu metode (Arikunto, 2013). Dengan kata lain metode tidak dapat memenuhi fungsinya dengan efektif apabila instrumen yang menjadi alat dari metode itu adalah valid. Instrument penelitian identik dengan alat pengumpul data. Didalam suatu penelitian, pengumpulan data harus dilakukan, karena masalah yang ada dalam penelitian akan dijawab dari proses pengumpulan data dan pengolahan data. Pengumpulan data, tentunya harus menggunakan suatu alat atau instrument yang dirancang, dikonstruksi atau disusun sedemikian rupa sesuai dengan jenis, masalah dan tujuan penelitian (Sunarno \& Sihombing (2011).

Adapun instrument yang digunakan untuk mendapatkan data penelitian sebelum dan sesudah perlakuan adalah ketepatan smash.

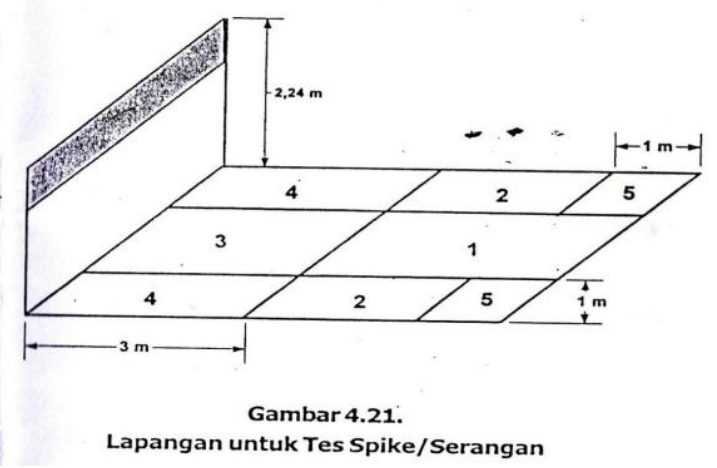

Sumber: Nurhasan (1986) Tes Dan Pengukuran Pendidikan Olahraga.

\section{Cara menskor:}

1. Bola yang menyentuh batas sasaran, dihitung telah masuk sasaran dengan angka yang lebih besar.

2. Skor $=0$, jika pemukul menyentuh jaring dan atau jatuh diluar sasaran. 
3. Sebagai contoh cara menskor tes spike/serangan adalah sebagai berikut:

Kesempatan pukalan pertama skor : 5

Kesempatan pukulan kedua skor : 4

Kesempatan pukulan ketiga skor : 3

Kesempatan pukulan keempat skor : 2

Kesempatan pukulan kelima skor : 1

Jadi skor tes spike adalah skor : 17

\section{Tehnik Pengumpulan Data}

Pengumpulan data adalah prosedur yang sistematis dan standar untuk memperoleh data yang diperlukan dalam suatu penelitian (Sunarno \& Sihombing, 2011). Ada beberapa jenis metode pengumpulan data yang umum dipakai yaitu metode tes, agket atau kuesioner, interview, observasi, skala bertingkat (rating), dan dokumentasi. Sedangkan dalam penelitian ini digunakan dua teknik pengumpulan data yaitu:

1. Dokumentasi

Teknik dokumentasi digunakan untuk mendapatkan data tentang jumlah siswa, dan berupa dokumentasi gambar ketika melakukan penelitian.

2. Tes perbuatan

Teknik pengumpulan data yang digunakan adalah berbentuk test praktek berupa kemampuan smash siswa sebelum dan setelah diberikan perlakuan, dengan prosedur pelaksanaan sebagai berikut:

a. Testee berada dalam daerah serang atau bebas di dalam lapangan permainan.

b. Bola dilambungkan atau diumpan dekat atas jaring kearah testee.

c. Dengan atau tanpa awalan, testee meloncat dan memukul bola melampaui atas jaring ke dalam lapangan di seberangnya dimana terdapat sasaran dengan angka-angka, dari skor 1-5.
d. Teste
diberikan
kesempatan
melakukan smash sebanyak 5 kali

\section{Tehnik Analisa Data}

Analisa data adalah teknik yang digunakan untuk mengolah data penelitian. Menurut (Sunarno \& Sihombing 2011) baik buruknya analisa data sangat tergantung pada data yang dikumpulkan, baiknya data yang terkumpul sangat tergantung pada baiknya instrument penelitian. Pada penelitian ini teknik analisis data menggunakan rumus t-test untuk sampel sejenis, karena menurut
(Maksum, 2009) bila kita ingin menganalisis perbedaan antara hasil pretest dan postest pada kelompok tertentu, maka dapat kita gunakan T-test sampel sejenis. Adapun rumus yang dimaksudkan adalah:

$$
t=\frac{\sum D}{\sqrt{\frac{N \sum D^{2}-\left(\sum D\right)^{2}}{N-1}}}
$$

Keterangan :

$\mathrm{D}=$ Perbedaan setiap pasangan skor (pretest-

postest).

$\mathrm{N}$ = Jumlah sampel

\section{HASIL PENELITIAN DAN PEMBAHASAN \\ Hasil Penelitian}

Sesuai dengan rumus yang digunakan adalah uji t-test persamaan sampel, maka tabel tersebut akan berisikan tentang informasi tentang kemampuan smash awal (pre-test) siswa dam kemampuan akhir siswa (post-test). Tabel pre-test kemampuan smash siswa dapat dilihat pada tabel 1 dibawah ini:

\begin{tabular}{|c|c|c|c|c|c|c|c|}
\hline \multirow[b]{3}{*}{ No. } & \multirow[b]{3}{*}{ Nama } & \multicolumn{5}{|c|}{ Data Hasil Pre Test } & \multirow{3}{*}{$\underset{\text { h }}{\text { Jumla }}$} \\
\hline & & \multicolumn{5}{|c|}{ Ketepatan smash } & \\
\hline & & 1 & 2 & 3 & 4 & 5 & \\
\hline 1 & Joni Pratama & 1 & 1 & 1 & 3 & 3 & 9 \\
\hline 2 & Muhammad. Multazam Makbul & 3 & 3 & 3 & 1 & 0 & 10 \\
\hline 3 & Hisbulloh Sasaki & 1 & 2 & 2 & 2 & 4 & 11 \\
\hline 4 & Habib Run Zaen Hadi & 1 & 3 & 3 & 2 & 1 & 10 \\
\hline 5 & M. Riki Gunawan & 3 & 2 & 2 & 1 & 2 & 10 \\
\hline 6 & Wahyu Pratama & 2 & 1 & 2 & 2 & 3 & 10 \\
\hline 7 & Maliki & 2 & 3 & 2 & 3 & 1 & 11 \\
\hline 8 & Muhammmad Arifin & 1 & 3 & 2 & 1 & 2 & 9 \\
\hline 9 & Fahrurrozi & 3 & 2 & 3 & 0 & 3 & 11 \\
\hline 10 & Rizky Hidadayat & 2 & 2 & 1 & 3 & 1 & 9 \\
\hline 11 & Salaman Alfarisi & 4 & 1 & 1 & 2 & 3 & 11 \\
\hline 12 & Agus Suprianato & 1 & 1 & 1 & 2 & 3 & 8 \\
\hline 13 & M. Zaki Irwansyah & 1 & 3 & 3 & 3 & 1 & 11 \\
\hline 14 & Muhammada Habibullah & 1 & 3 & 1 & 1 & 2 & 8 \\
\hline 15 & Muhammad Darul Fikri & 3 & 3 & 2 & 2 & 1 & 11 \\
\hline 16 & Muhammad Syabani Amri & 2 & 2 & 1 & 3 & 1 & 9 \\
\hline 17 & Rianto & 2 & 2 & 3 & 1 & 0 & 8 \\
\hline 18 & Ujang Agasiwi & 3 & 2 & 0 & 2 & 4 & 11 \\
\hline 19 & Yogi Zaenanda & 3 & 0 & 0 & 3 & 3 & 9 \\
\hline 20 & Ibnu Risaman Sanjaya & 1 & 1 & 1 & 3 & 2 & 8 \\
\hline 21 & Muhammad Suryadi & 2 & 3 & 3 & 0 & 1 & 9 \\
\hline 22 & Matori Abdurahman & 4 & 3 & 0 & 3 & 2 & 12 \\
\hline 23 & Muhammad Basri & 3 & 0 & 1 & 3 & 2 & 9 \\
\hline 24 & Topan Alfarisi & 3 & 2 & 3 & 2 & 1 & 11 \\
\hline 25 & Ahamad Jaelaani Sidiik & 1 & 3 & 3 & 1 & 3 & 11 \\
\hline 26 & Heri Kurniawadi & 3 & 1 & 2 & 0 & 2 & 8 \\
\hline
\end{tabular}




\begin{tabular}{|c|l|c|c|c|c|c|c|}
\hline \multirow{2}{*}{ No. } & \multirow{2}{*}{ Nama } & \multicolumn{4}{|c|}{ Data Hasil Post-Test } & \multirow{2}{*}{} \\
\cline { 2 - 6 } & & \multicolumn{3}{|c|}{ Ketepatan smash } & \\
\cline { 2 - 6 } & & $\mathbf{1}$ & $\mathbf{2}$ & $\mathbf{3}$ & $\mathbf{4}$ & $\mathbf{5}$ & Jumlah \\
\hline 2 & Joni Pratama & 3 & 3 & 3 & 2 & 1 & 12 \\
\hline 3 & Muhammad. Multazam Makbul & 3 & 3 & 2 & 3 & 3 & 14 \\
\hline 4 & Hisbulloh Sasaki & 3 & 4 & 1 & 2 & 1 & 11 \\
\hline 5 & Habib Run Zaen Hadi & 3 & 2 & 3 & 4 & 2 & 14 \\
\hline 6 & M. Riki Gunawan & 1 & 4 & 3 & 1 & 1 & 10 \\
\hline 7 & Mahyu Pratama & 3 & 3 & 3 & 1 & 3 & 13 \\
\hline 8 & Muhammmad Arifin & 3 & 4 & 3 & 1 & 1 & 12 \\
\hline 9 & Fahrurrozi & 2 & 4 & 1 & 3 & 1 & 11 \\
\hline 10 & Rizky Hidadayat & 3 & 3 & 2 & 2 & 3 & 13 \\
\hline 11 & Salaman Alfarisi & 2 & 2 & 3 & 1 & 2 & 10 \\
\hline 12 & Agus Suprianato & 2 & 1 & 2 & 4 & 1 & 10 \\
\hline 13 & M. Zaki Irwansyah & 1 & 3 & 3 & 3 & 2 & 12 \\
\hline 14 & Muhammada Habibullah & 4 & 2 & 3 & 2 & 1 & 12 \\
\hline 15 & Muhammad Darul Fikri & 3 & 2 & 1 & 3 & 1 & 10 \\
\hline 16 & Muhammad Syabani Amri & 2 & 2 & 3 & 3 & 3 & 13 \\
\hline 17 & Rianto & 2 & 3 & 2 & 3 & 3 & 13 \\
\hline 18 & Ujang Agasiwi & 2 & 3 & 2 & 3 & 3 & 13 \\
\hline 19 & Yogi Zaenanda & 1 & 1 & 3 & 3 & 3 & 11 \\
\hline 20 & Ibnu Risaman Sanjaya & 3 & 2 & 1 & 2 & 3 & 11 \\
\hline 21 & Muhammad Suryadi & 2 & 2 & 4 & 2 & 1 & 11 \\
\hline 22 & Matori Abdurahman & 3 & 3 & 3 & 2 & 3 & 14 \\
\hline 23 & Muhammad Basri & 3 & 3 & 3 & 2 & 2 & 13 \\
\hline 24 & Topan Alfarisi & 2 & 2 & 3 & 1 & 3 & 11 \\
\hline 25 & Ahamad Jaelaani Sidiik & 1 & 2 & 4 & 3 & 3 & 13 \\
\hline 26 & Heri Kurniawadi & 2 & 3 & 2 & 2 & 4 & 13 \\
\hline 27 & Imam Wahyudi & 2 & 1 & 3 & 3 & 3 & 12 \\
\hline 28 & Muhammad Dandin Setiawan & 2 & 1 & 4 & 3 & 2 & 12 \\
\hline 29 & Muhammad Yusuf & 3 & 3 & 2 & 2 & 13 \\
\hline 30 & Ahmad Buasairi & 2 & 3 & 3 & 2 & 1 & 12 \\
\hline & & & 1 & 3 & 10 \\
\hline
\end{tabular}

Adapun tabel kerja pre-test dan psottest kemampuan smash mahasiswa UKM bola voli IKIP Mataram yang berjumlah 30 orang di analisa dengan menggunakan rumus t-test persamaan sampel adalah sebagai berikut:

\section{Tabel 1 hasil smash siswa pree-test dan}

\section{post-test}

\begin{tabular}{|c|c|c|c|c|}
\hline \multirow{2}{*}{$\begin{array}{c}\text { No. } \\
\text { Sub.jek }\end{array}$} & \multicolumn{2}{|c|}{ Knee Tuck Jump } & \multirow[b]{2}{*}{ D } & \multirow[b]{2}{*}{$\mathbf{D}^{2}$} \\
\hline & Pre-test ( $\left.T_{1}\right)$ & Post-test $\left(\mathrm{T}_{2}\right)$ & & \\
\hline $\mathbf{1}$ & 2 & 3 & 4 & 5 \\
\hline 1 & 9 & 12 & 3 & 9 \\
\hline 2 & 10 & 14 & 4 & 16 \\
\hline 3 & 11 & 11 & $\mathrm{O}$ & $\mathrm{O}$ \\
\hline 4 & 10 & 14 & 4 & 16 \\
\hline 5 & 10 & 10 & $\mathrm{O}$ & $\mathrm{O}$ \\
\hline 6 & 10 & 13 & 3 & 9 \\
\hline 7 & 11 & 12 & 1 & 1 \\
\hline 8 & 9 & 11 & 2 & 4 \\
\hline 9 & 11 & 13 & 2 & 4 \\
\hline 10 & 9 & 10 & 1 & 1 \\
\hline 11 & 11 & 10 & -1 & 1 \\
\hline 12 & 8 & 12 & 4 & 16 \\
\hline 13 & 11 & 12 & 1 & 1 \\
\hline 14 & 8 & 10 & 2 & 4 \\
\hline 15 & 11 & 13 & 2 & 4 \\
\hline 16 & 9 & 13 & 4 & 16 \\
\hline 17 & 8 & 13 & 5 & 25 \\
\hline 18 & 11 & 11 & $\mathrm{O}$ & $\mathrm{O}$ \\
\hline 19 & 9 & 11 & 2 & 4 \\
\hline 20 & 8 & 11 & 3 & 9 \\
\hline 21 & 9 & 14 & 5 & 25 \\
\hline
\end{tabular}

\section{Pembahasan}

Dari tabel kerja diatas, maka dapat dihitung nilai t-test persamaan sampel sebagai berikut:

$$
\begin{aligned}
& \sum \mathrm{D}=64 \\
& \begin{aligned}
\sum \mathrm{D}^{2} & =206 \\
\mathrm{~N} & =30
\end{aligned} \\
& \text { Maka: } \\
& t=\frac{\sum D}{\sqrt{\frac{N \sum D^{2}-\left(\sum D\right)^{2}}{N-1}}} \\
& t=\frac{64}{\sqrt{\frac{6180-4096}{29}}} \\
& t=\frac{64}{\sqrt{71.86}} \\
& t=\frac{64}{8.48} \\
& \mathrm{t}=7.55 \\
& \mathrm{df}=30-1=29 \\
& \mathrm{t}(29)=7.55 . \mathrm{p}<0.05
\end{aligned}
$$

Berdasarkan hasil pengolahan data diperoleh suatu data yang cukup membuktikan bahwa dengan latihan knee tuck jump yang sistematis dan terprogram dapat meningkatkan kemampuan smash dalam permainan bola voli. Dengan hasil yang dapat dibuktikan dari perhitungan analisis statistik uji t yaitu diperoleh nilai t-hitung > t-tabel, dengan kata lain $(7.55>2,045)$ pada taraf signifikan 5\%. Dengan derajat kebebasan (df) $\mathrm{N}-1$ (30-1) = 29. Hal tersebut mengindikasikan bahwa latihan knee tuck jump efektif dalam meningkatkan kemampuan smash dalam permainan bola voli. Hal ini sejalan dengan penelitian yang telah dilakukan oleh (Syahfrizar, 2007) latihan knee tuck jump \& box jump secara signifikan dapat meningkatkan daya ledak otot tungkai atlet bolavoli.

\section{KESIMPULAN}

Berdasarkan pada penjelasan bab 4 dalam penelitian ini, khususnya untuk menjawab rumusan masalah dan tujuan penelitian pada bab 1 (satu) dan hasil pembahasan pada bab 4 (empat) dengan perolehan angka t-hitung sebesar 7.55 dan t- 
tabel sebesar 2,045, atau dengan kata lain (7.55 > 2.045), maka dapat ditarik suatu kesimpulan dalam penelitian, bahwa "latihan knee tuck jump mempunyai pengaruh yang signifikan terhadap peningkatan kemampuan smash Mahasiswa UKM Bolavoli IKIP Mataram".

\section{DAFTAR PUSTAKA}

Arikunto, Suharsimi. 2013. Prosedur Penelitian Suatu Pendekatan Praktek. Jakarta: Rineka Cipta.

Hatmisari, Dwi Ambarukmi. 2007. Pelatihan Fisik Level 1. Asdep Pengembangan Tenaga dan Pembinaan Keolahragaan Deputi Bidang Peningkatan Prestasi dan IPTEK Olahraga Kementrian Negara Pemuda dan Olahraga.

Kurniawan, F. 2012. Buku Pintar Pengetahuan Olahraga. Jakarta: Laskar Aksara.

Maksum, Ali. 2009. Metode Penelitian dalam Olahraga. Surabaya: Fakultas Ilmu Keolahragaan. Universitas Negeri Surabaya.

Nurhasan, 1986. Tes Dan Pengukuran. Jakarta: Universitas Terbuka.

PBVSI, 2005. Peraturan Permainan Bolavoli. Jakarta: PBVSI.

Prasetyo, Sudarmono Trisno Bagus, 2013. Smash Dalam Permainan Bola Voli. http://sudarmono23.blogspot.com/201 3/06/smash-dalam-permainan-bola voli.html, diakses tanggal 27 September 2014.

Syahfrizar, 2007. Latihan Knee Tuck Jump Dan Box Jump Untuk Atlet Bolavoli. Padang: Wineka Media.

Sugiyono. 2010. Metode Penelitian Pendidikan (Pendekatan Kuantitatif, Kualitatif, dan $R \& D)$. Bandung: Alfabeta.

2013. Metode
$\begin{aligned} & \text { Pendidikan (Pendekatan } \\ & \text { Kualitatif, }\end{aligned}$ Kuantitatif,
Alfabeta.

Suharno, 1982. Teknik Permainan Bola Voli. Bandung: Arkola.

Sukadiyanto \& Muluk. 2011. Pengantar Teori dan Melatih Fisik. Bandung: Lubuk Agung Bandung.
Sunarno \& Sihombing, 2011. Metode Penelitian Keolahragaan. Medan: Yuma Pustaka.

Yunus, Muhammad. 1992. Permainan Bola Besar. Jakarta: Rineka Cipta 